Maurer School of Law: Indiana University

Digital Repository @ Maurer Law

1979

\title{
The Sentence Bargaining of Upperworld and Underworld Crime in Ten Federal District Courts
}

Ilene Nagel Bernstein

Indiana University School of Law - Bloomington

John Hagan

University of Toronto

Follow this and additional works at: https://www.repository.law.indiana.edu/facpub

Part of the Criminal Law Commons, and the Criminology and Criminal Justice Commons

\section{Recommended Citation}

Bernstein, llene Nagel and Hagan, John, "The Sentence Bargaining of Upperworld and Underworld Crime in Ten Federal District Courts" (1979). Articles by Maurer Faculty. 2069.

https://www.repository.law.indiana.edu/facpub/2069

This Article is brought to you for free and open access by the Faculty Scholarship at Digital Repository @ Maurer Law. It has been accepted for inclusion in Articles by Maurer Faculty by an authorized administrator of Digital Repository @ Maurer Law. For more information, please contact rvaughan@indiana.edu. 


\title{
THE SENTENCE BARGAINING OF UPPERWORLD AND UNDERWORLD CRIME IN TEN FEDERAL DISTRICT COURTS
}

\author{
JOHN HAGAN \\ ILENE NAGEL BERNSTEIN
}

\begin{abstract}
This paper explores the use of different types of sentence bargaining tactics in ten federal district courts. We distinguish between proactive and reactive prosecutorial orientation, and hypothesize that proactive prosecution of upperworld crime is associated with more explicit sentence bargaining than is the reactive prosecution of underworld crime. We present evidence for and explanations of this relationship.
\end{abstract}

This paper is concerned with plea negotiations involving sentence bargaining in United States District Courts. Federal courts are interesting in part because, unlike state courts, they have the capacity and jurisdiction to prosecute many forms of upperworld crime, although they do not always exercise that authority. Our thesis is that a prosecutorial focus on upperworld crimes in the federal district courts is associated with the use of specific types of bargaining tactics that involve a strategic and explicit juxtaposition of coercive threats and promised concessions. The social organization of these and other tactics is the subject of our discussion.

\section{STUDYING STATE AND FEDERAL COURTS}

Most research on plea negotiation, and criminal justice processing more generally, has focused on state courts. In contrast, research reported in this paper is based on fieldwork done on federal courts in ten districts: Northern and Southern New York, Northern Illinois, Eastern Pennsylvania, Maryland, Northern Texas, Eastern Missouri, Northern Georgia, Central California, and Eastern Michigan. Selection of these ten districts was determined by the Administrative Office of the United States Courts, the agency that collected a large body of archival data used in other parts of our research. In this paper

This research was supported by a grant from the National Institute of Mental Health. The article represents our own views and not necessarily those of NIMH. The findings reported in this paper are exploratory and will be pursued further in a monograph in preparation by the authors. A further discussion of the distinction between proactive and reactive prosecutor's offices can be found in Bernstein and Hagan (1978). 
we consider qualitative data obtained through site visits to each of the ten districts, during which we observed approximately 200 hours of court proceedings and conducted approximately 600 hours of interviews with court personnel involved in decisionmaking in criminal cases: the Chief Judge and three to five presiding judges, the United States Attorney and Assistant United States Attorneys responsible for subsections of the office dealing with criminal matters, the Chief Probation Officer, the Head of the Pre-Trial Services Agency, the Senior Magistrate and a sample of other Magistrates who handle criminal cases, the Chief of the Public Defender Office, and private attorneys who frequently handle criminal cases. It is these interview data that are discussed most extensively in this paper.

\section{STATE AND FEDERAL CRIMINAL JUSTICE}

The distinction drawn between the state and federal syctems is an important one with significant implications for prosecutorial negotiation and coercion. The salient feature of state courts is that they are organized almost exclusively to respond to cases brought to them by local police. In large part, this stems from the fact that municipal police work is heavily "reactive," that is, responsive to citizen complaints (Black, 1973). In other words, the state courts respond largely to being overburdened. Faced with a large number of police processed citizen complaints, most state courts have little recourse but to process as efficiently as possible the volume and types of cases they receive. To do otherwise would be to undercut police and public support (see Reiss, 1971), for the state courts are, in effect, "courts of last resort."

In contrast, the federal courts have much greater potential for selectively determining the composition and size of their case loads, although they do not always develop this potential. Despite the fact that federal courts receive the bulk of their case referrals from federal enforcement agencies (e.g., the Federal Bureau of Investigation, the Drug Enforcement Agency, and the Internal Revenue Service), they are not limited to agency input. Some offices have their own investigative agents. Furthermore, by working closely with federal prosecutors, the enforcement agencies can play a more creative role in "proactively" determining which areas of enforcement the court will emphasize. As a result, federal courts frequently devote considerable attention to the prosecution of upperworld as well as 
underworld crime. This point is well-illustrated by the following excerpt from an interview with an Assistant United States Attorney in one of the most proactive offices we encountered.

$[\mathrm{T}]$ he way I operate is I basically initiate grand jury investigations where I think it is appropriate. The _ case, which was a major land sales fraud case, is a very good example of that. Basically my philosophy is that the resources here are limited. . . . You can never prosecute all the crimes that are being committed, and you can never prosecute all the white-collar crimes. Going into the decisionmaking process for me are the following: (1) I want it to be obviously a case with federal impact-that is, a federal problem that we are looking at, and not a local state problem; (2) that the impact is broad; and (3) for me particularly I prefer to make cases in areas where nothing has been done. In other words, to focus on an industry or problem where there has not been a criminal prosecution. . . . So, I will pick an area such as land fraud where there was a lot of good information about serious abuses but no criminal prosecutions and begin a grand jury investigation. And that resulted in the —_ case being brought and successfully prosecuted. And there are other areas. . . I will just focus on areas where there really hasn't been federal criminal enforcement, areas which have a consumer impact, and develop cases in those areas.

In contrast to the proactive orientation toward federal prosecution just noted, it is interesting to consider the following response encountered in a much more reactive U.S. Attorney's Office, using the very concepts we have suggested:

For the most part, they [the enforcement agencies] are the experts. They know whether there is a crime and they know how to prove it. They will get the facts and bring us a package and there it is. I don't know the FBI in Chicago, but I would imagine . . . more [the U.S. Attorney] sitting down with the FBI and saying, "Okay, I want to go after political corruption, let's go get it." ... . We are basically a reactive agency and before setting priorities we have to consider that. We can't just shut down our reactive side and go proactive and say "I'm sorry we can't accept complaints now because we are too busy doing this." We have to respond to the needs of all agencies and enforce the law.

The latter approach produces a caseload composed largely of conventional underworld (e.g., "street") crime.

Based on such responses, we have concluded that the federal districts we have studied can be placed on a continuum from "reactive" to "proactive" in terms of their allocation of court resources and organizational orientations toward prosecutorial discretion. Our interest is in the connection between this allocation of court resources, the resulting caseloads, and the form prosecutorial negotiations take. Before pursuing this issue, however, we need to consider some specific differences between plea negotiations in the state and federal systems.

\section{PLEA BARGAINING IN STATE AND FEDERAL COURTS}

Ground rules for plea negotiations in the federal courts are outlined in Rule 11 of the Federal Rules of Criminal Procedure: (1) charges may be reduced to lesser or related offenses; (2) 
the U.S. Attorney may promise to move to dismiss other charges; (3) the U.S. Attorney may agree to recommend (or not to oppose) the imposition of a particular sentence; and (4) the U.S. Attorney and the defense attorney may agree that a given sentence is an appropriate disposition of the case, with the defendant's promise to plead guilty binding only if the court agrees to that sentence. What distinguishes state and federal courts is that the first of these possibilities, charge reduction, is extremely common in the state courts (see, e.g., Sudnow, 1965; Hagan, 1975; Bernstein et al., 1977) and relatively infrequent in federal courts.

The reason for this difference is that state criminal codes include lesser offenses to which charges frequently can be reduced, whereas the federal criminal code typically does not. This point was made by an Assistant U.S. Attorney with experience in both systems:

[T] $T$ he state experience was that you could do a lot of wheeling and dealing as a defense lawyer. ... A lot of fictions are entered into. For instance, with the elements. In order to get within a lesser included offense, people kind of fudge the facts a bit. . . . Let me give you an example ... when I had the experience, breaking and entering was a ten year maximum and a person might plead to entering without breaking with intent to commit a larceny, which was a five year maximum even though they broke. You get into those kind of games. . . . I've seen people plead guilty in the state system to attempted possession of narcotics, and I think that is pretty hard to do!

The problem federal prosecutors face is that the federal criminal code less frequently includes graded offenses. A result is more explicit recourse to discussions of sentencing and related sanctions. In following sections of this paper we explore the hypothesis that as a U.S. Attorney's Office becomes more proactive in its orientation and allocation of resources, and thereby pursues the prosecution of upperworld as well as underworld offenders, discussions of sanctioning become a more explicit part of the bargaining process. In essence, we are suggesting a relationship between the creative use of prosecutorial resources and the use of explicit threats and promises in the federal district courts.

\section{THE SOCIAL ORGANIZATION OF PROACTIVE JUSTICE}

Making a U.S. Attorney's office more proactive in orientation is accompanied by the creation of new types of cases, cases that are usually expensive and protracted in their development. Particularly in the areas of white-collar crime and political corruption, it is often difficult to develop the type of evidence required for successful prosecutions. A basic problem is clearly identified by an Assistant U.S. Attorney: "It's not like 
a bank robbery where you have eyewitnesses that didn't take part in the crime, but merely saw it happen. You don't have that in official corruption . . . [here] the only people that know about the crime are the people that are involved in the crime." In short, a means must be developed for "turning witnesses" and securing their "cooperation" in the prosecution of a case.

We therefore sought to identify the techniques used by prosecutors. Their range is suggested candidly in the following interview:

Q: How do you urge cooperation from defendants?

A. We threaten to send them to jail. It's the most effective way we've ever done it. We make a good, solid case on them and hang it over their head like a hammer.

Q: And what are the mechanics of doing that, how exactly do you present it to the defendant?

A. We tell them "if you don't cooperate, we will convict you. And we will do it in a way that will make you look-we'll do it so well that you would get really good jail time, a solid big chunk of time."

Q. At what stage do you do this?

A. Well, we are willing to make deals with people in a whole host of ways running all the way from giving them a "pass" to they just don't get prosecuted at all in return for testifying.

Q. Do you usually indict them first?

A: We make deals at all stages. ... We talk to them before indictment in the very big cases. Then we have all kinds of pleas like a guy has committed a felony. We'll let him plead to a misdemeanor and won't prosecute . . . a whole range of things all the way 'till he pleads to the principal count ... to charging him with exactly what he did and saying nice things about him at sentencing.

The possibilities, then, are numerous and potentially coercive.

Promises of concessions as well as threats of coercion are also part of the bargain a federal prosecutor can offer a "cooperative" defendant. A standard operating rule is "first in, best out."

Q: Is there anything that suggests that one defendant should get a better deal than another?

A: Yes. As soon as I heard there was an investigation into an area in which I knew I was criminally involved, I would run to the U.S. Attorney's Office and say, "Look, I will tell you all about it."

Q: You mean you reward those who come first?

A: Well, typically you have to work it-it's kind of a callous way to approach it, but you have to work "first in, best out." That is the way you have to do it. It is unfortunate, but say you've offered a deal to somebody and he rejects it and the next guy takes it; well, if you go back to the first guy or he comes back to you, he's no longer the first. So he doesn't get as good a deal as the first in. It's the way you have to work and the defense lawyers know it.

A graded set of outcomes is particularly important in negotiations with public officials charged with corruption, who often persist in maintaining their innocence "on the courthouse steps." Graded outcomes counter this tendency to "stonewall."

Federal prosecutors emphasize the importance of communicating their intentions and actions, as well as the consequences of those actions, to the community of defense lawyers. 
The bar has got to be conditioned to flipping people. You can't do it by yourself. You have got to have a sophisticated defense attorney on the other side who knows when it is in their client's interest to cooperate.

You may today be up against a lawyer and arguing one side of a case for the conviction of his client and the next day be with that same lawyer and he is turning another client to become a witness for the government. So you have to establish your credibility because we all work together and the cooperation of the bar is something that a prosecutor's office needs in order to be effective. They have to know that when they turn their client we will do what we say we will do and if we don't say that we will do it, then we won't do it.

Essential to generating cooperation and establishing credibility, of course, is a shared understanding between prosecution and judiciary that negotiated agreements will be performed and expectations fulfilled. Our interviews suggest that this exists at the levels of both practice and principle. On a practical level, the following comment of an Assistant U.S. Attorney is representative of a view common in proactive offices: "I would say most judges understand that in order to expose official corruption you do have to give some concessions to people who are involved. Again, because only those people who are involved know and can testify about it." Even more interesting, however, is the way this practical need is coordinated with the principles of sentencing: cooperation is treated as a sign of contrition and thus predictive of rehabilitation. That this is more rationalization than reason is suggested in the following excerpt from the interview just quoted:

I would say the judges do give some consideration simply because it does show contrition and judges are going to disagree with me on this but, when a federal district court judge gets to the point of passing sentence upon people, he is acting not only as a representative of the people but he is also acting as a law enforcement officer, because whatever sentence he gives may bring about cooperation and may cause him [the defendant] to tell the U.S. Attorney about other criminal activity.

The prosecutor at least is concerned with the practical first and the ideal second.

We have established, then, that there are a number of ways of eliciting cooperation from defendants, and that this type of negotiation, using a mix of promised concessions and threatened coercion, is very important to proactive prosecution. In the next section of this paper, we examine more specifically how these factors influence sentence bargaining by reactive and proactive prosecutors in the federal courts.

\section{BARGAINING PROCESSES}

One of the most explicit forms of sentence bargaining provided in the Federal Rules of Criminal Procedure is a formal 
plea agreement concerning the recommendation the prosecution will or will not make to the judge. One of our major concerns, then, is to determine how the use of sentence recommendations by prosecutors is related to the organizational orientations of the ten jurisdictions we have studied.

TABLE 1

Cross-Classification of Organizational Orientation and Sentence Recommendation Policy

\begin{tabular}{|c|c|c|}
\hline \multirow[b]{2}{*}{$\begin{array}{l}\text { Organizational } \\
\text { Orientation }\end{array}$} & \multicolumn{2}{|c|}{ Sentence Recommendation Policy } \\
\hline & $\begin{array}{l}\text { Infrequently } \\
\text { recommend } \\
\text { sentence }\end{array}$ & $\begin{array}{c}\text { Frequently } \\
\text { recommend } \\
\text { sentence }\end{array}$ \\
\hline Reactive & 2 & 0 \\
\hline Balanced & 1 & 3 \\
\hline Proactive & 1 & 3 \\
\hline
\end{tabular}

In Table 1 we have categorized our ten districts in terms of organizational orientation and use of prosecutorial recommendations for sentence. The districts were first dichotomized into those in which prosecutors frequently and infrequently recommend sentences. We then divided organizational orientation into three categories-reactive, balanced, and proactive. Proactive jurisdictions, it will be recalled, are unique in their emphasis on upperworld as well as underworld crime. Balanced jurisdictions are those that are trying both to service the demands of enforcement agencies as well as to develop new areas of prosecution in a more proactive manner. Reflective of this orientation is the following excerpt from an interview with a U.S. Attorney in a district we have categorized as balanced:

The key to a successful office is in "alliance," and that is the word with the investigative agencies. They have their needs and one of them is they need their statistics to satisfy their bosses. . . W We've gotten along fabulously in this district with the IRS and the FBI. We do a little back-scratching. . . . We will not cut off the FBI and bank robbers and so on. ... They need statistics. They need to be able to beat the drum a little bit. And I've got to help them and I will. . . . If you can figure out a creative way to both relieve yourself of some of the burden and still get statistics for the FBI, that is great. It is all part of the game. I'm trying to do that here.

Although we clearly are limited in the number of districts from which we can draw our conclusions, the results presented in Table 1 provide preliminary evidence in support of our hypothesis. The reactive districts in our small sample infrequently involve prosecutors in sentence recommendations, while the balanced and proactive districts frequently do.

The involvement of prosecutors in recommending sentences makes the process of sentence bargaining rather explicit. This does not mean, of course, that such bargaining is 
not prevalent, albeit less explicit, in reactive districts, or that there are not other forms of explicit sentence bargaining in balanced and proactive districts. Indeed, by considering several of our districts in greater detail, we will be able to provide more exploratory evidence in support of our proposition. We will consider the two reactive districts first.

Less explicit sentence bargaining occurs in at least two different ways in the first of our reactive districts. The most frequent approach is to drop counts and thereby limit the total exposure to sentence.

We can bargain on counts, but we can't guarantee a probated sentence or a certain amount of time. We can cut down the exposure. . . . Say that you take the big dope case. You got the guy on five counts and he is exposed to fifteen years on each count. You know darn well the judge isn't going to give fifteen years. So why not say "okay, we'll drop off three counts."

In this case, then, the concession may be more apparent than real: the defendant may get the same sentence regardless of how many counts are included, and there is no clear indication of what that sentence might be. Nevertheless, the defendant is reacting to a set of outcomes that are perceived to be real, and therefore are real in terms of their consequences for the bargaining process.

A second approach used in this reactive district is adopted in cases where the defendant is providing more extensive cooperation. Information about this cooperation is relayed to the judge either through the probation department's presentence report or in a more confidential manner. An Assistant U.S. Attorney describes these procedures:

In a normal situation where the guy wants to cooperate, and he doesn't care who knows about it, we usually go through the probation office and tell the person who draws up the presentence investigation what the guy has done and make sure that cooperation gets passed along to the judge. . . . However, this could also be done ahead of time in chambers. The Defense Attorney and I may go into the judge ahead of time and say- "Judge, I want to tell you [about] this man's cooperation. He doesn't want it on the record"-and the attorney will explain. And even if we make it known to the probation officer, if the guy wants us to make real sure that the judge knows about it and wants us to tell the judge again, we will tell the judge again. I have no qualms about telling the judge what a guy has done.

This latter approach offers a sharp contrast to the practice of having plea agreements presented formally to the court, although the results may be the same. Similarly, the use of presentence reports to relay information about prosecutorial negotiations is somewhat at odds with the traditional role of probation officers in assessing the defendant's potential for rehabilitation. As noted earlier, the rationalization that cooperation is a measure of contrition is not very convincing. 
The second of the reactive districts we considered utilizes a more unusual set of procedures in which the key figure is the Chief Magistrate. The U.S. Attorney in this district notes that this Magistrate "has a unique role in the sense that he envisions himself as sort of an expeditor of pleas, and the district judges rely on him a great deal to sort of act as a traffic cop in shuffling these criminal cases through by obtaining the necessary pleas." The Magistrate performs this role through the use of the pretrial conference.

The pre-trial conference is theoretically to iron out matters that may be coming up and to clarify the parties' positions on various items. . . . Now the real purpose of the pre-trial conference as run by our Magistrate is to induce a plea of guilty. [The Magistrate] gets in there and he gets a defendant that will not plead guilty. . . Then he simply tells him that "we've got a visiting judge coming in here from South Dakota and he is a real hanger and I'm pretty sure if you go to trial that you're going to get him on the draw." Finally, he tells him "the Judge wants to know what you are going to do. I've got to have that information. ...."

This technique has worked very effectively in expediting the bargaining process.

We turn finally to the two more proactive districts that do not use prosecutorial sentence recommendations as a means of sentence bargaining, in order to determine if those "negative" cases contradict our hypothesis or simply employ some other explicit technique to accomplish similar goals. Both follow a similar policy. Assistant U.S. Attorneys "speak to the sentence," even if they do not make a specific recommendation, and also write "sentencing memos" to judges. One Assistant noted that "we have a practice here of submitting sentencing memos particularly in significant cases to bring to the judge's attention any information which we think is appropriate to the sentence. We do that in the white-collar cases for sure." The extent to which these practices are correlated with a proactive interest in white-collar crime, and ultimately with sentence bargaining, becomes apparent in the following excerpt from an interview with one of the U.S. Attorneys responsible for developing these policies.

Indeed we do not only take a position in sentencing in this office, in most crimes at the time of sentencing we stand there and correct whatever mistakes are made in the record. In one area where we do get involved is white-collar crime, basically because unless we did almost everybody would walk out on probation. Our concern is that the public sense of equal administration of justice requires that jail terms be imposed no matter how wonderful their backgrounds. . . . So, yes, it does operate in our plea bargaining. . . . If we can avoid a trial, we may not suggest jail. If we do have to go through trial, you can expect that we will speak for a tough sentence, and we seem to be having some effect on the judges. 
Thus, although these more proactive districts do not make formal sentence recommendations, nonetheless, they do engage in functionally equivalent practices that are no less explicit.

\section{DISCUSSION AND CONCLUSIONS}

Evidence presented in the previous pages suggests that proactive prosecution of upperworld crime leads to more explicit sentence bargaining, whereas reactive prosecution of underworld crime involves less. In attempting to account for this correlation we emphasize that it has been observed at the aggregate level, so that we must be cautious in drawing inferences based on the attributes of individuals. Furthermore, our findings must be regarded as exploratory because of the small number of districts considered.

The most plausible explanation of our observed correlation focuses on three interrelated factors: the power and interests of two major actors-prosecutors and white-collar defendants-and the social organization of upperworld offenses. The most obvious element in this explanation is that white-collar defendants may use the power they frequently enjoy to extract explicit sentence bargains. Defense counsel for white-collar defendants, and the defendants themselves, are unlikely to accept the consequences of guilty pleas unless they are convinced that the disposition will be favorable. By contrast, those conventional underworld offenders, who are more experienced in the dispositional process and also effectively represented, may be willing to rely on less explicit, customary understandings. Furthermore, this variation in sentence bargaining practices may reflect more general differences between upperworld and underworld vocational styles.

Prosecutors pursuing upperworld offenders also have an interest in making their promises of concessions and threats of coercion explicit. The following excerpts from our interviews give some idea of the scale of resource investment required in the proactive prosecution of upperworld crime.

It is damn hard to ... successfully prosecute these kinds of cases. They [U.S. Attorneys] shouldn't go in unless they know how to do it and they frequently don't know how to do it.

It would be nice to investigate let's say public corruption. "Okay, FBI, I want you to go out and develop snitches in all the HEW places where they might be taking bribes". . but God knows how much time [that would take) and we don't have the resources to do that.

It is difficult-it is a very difficult process of trying to do everything that should be done and yet still allowing yourself to free up enough resources to do the cases that are more difficult and need to be done but aren't so obvious. There's always a balancing act that is very difficult. 
This type of investment in proactive prosecution may be sufficiently great that prosecutors are forced to extend themselves in ways that will increase the assurance of conviction, including explicit sentence bargaining.

The final factor to be considered parallels the preceding two and involves the social organization of upperworld crimes. As we indicated early in our discussion, part of the reason that upperworld cases are difficult to develop is the absence of a highly visible victim. Even though upperworld crimes clearly do have victims, the complexity and diffuseness of the victimization present some of the same problems for effective prosecution that arise in victimless crimes. Without victims to testify about the criminal events, it usually is necessary to cultivate sources of information and evidence from within the criminal operation. In conventional victimless crimes, police can develop such informers at the street level with money, drugs, and other material bribes or, failing this, through covert, implicit promises and threats (Skolnick, 1966). In contrast, upperworld witnesses and informers must be approached in more formal and publicly visible ways. Whether the inducement is a promise or threat, the arrangement is more likely to become explicit in character.

This explicit use of concessions and coercion in the proactive prosecution of upperworld crime has an important advantage: it is visible for public scrutiny and criticism in a way that most plea bargaining is not. It thereby forces the question: how many concessions and how much coercion is appropriate in the prosecution of upperworld or underworld crime? Such a question cannot be answered by empirical research.

\section{REFERENCES}

BERNSTEIN, Ilene and John HAGAN (1978) "Process and Outcome in the Study of Social Problems: Multiple Methods and Theoretical Transformations." Presented at the Second National Meeting of the Law and Society Association, Minneapolis (May 18-20).

BERNSTEIN, Ilene, Edward KICK, Jan LEUNG and Barbara SCHULZ (1977) "Charge Reduction: An Intermediary Stage in the Process of Labelling Criminal Defendants." 56 Social Forces 362.

BLACK, Donald (1973) "The Mobilization of Law," 2 Journal of Legal Studies 125.

BLUMBERG, Abraham (1967) Criminal Justice. Chicago: Quadrangle Books.

HAGAN, John (1975) "Parameters of Criminal Prosecution: An Application of Path Analysis to a Problem of Criminal Justice," 65 Journal of Criminal Law \& Criminology 536.

KLEIN, John (1976) Let's Make a Deal. Lexington, Mass.: Lexington Books.

REISS, Albert J. (1971) The Police and the Public. New Haven: Yale University Press. 
SKOLNICK, Jerome (1966) Justice without Trial: Law Enforcement in Democratic Society. New York: John Wiley.

SUDNOW, David (1965) "Normal Crimes: Sociological Features of the Penal Code in a Public Defender's Office," 12 Social Problems 255. 